\title{
PENENTUAN PERCEPATAN GRAVITASI LOKAL DI UNIVERSITAS SAM RATULANGI MANADO BERDASARKAN TEORI GETARAN HARMONIK
}

\author{
Handy Indra Regain Mosey ${ }^{1)}$, Benny Max Lumi ${ }^{1)}$ \\ ${ }^{1)}$ Program Studi Fisika FMIPA Universitas Sam Ratulangi Manado \\ e-mail: cici.heijie@gmail.com; bennylumi@gmail.com
}

\begin{abstract}
ABSTRAK
Penelitian ini bertujuan untuk menentukan besarnya nilai percepatan gravitasi lokal di Universitas Sam Ratulangi Manado. Metode yang digunakan dalam penelitian ini yaitu metode campuran yakni dengan perhitungan secara teoritis dengan menggunakan Hukum Gravitasi Newton dan Hukum II Newton dan metode eksperimen menggunakan bandul/ayunan matematis yang di dalamnya terdapat analisis numerik dan perhitungan galat/error. Dari analisis data eksperimen yang dilakukan didapatkan nilai gravitasi lokal dengan nilai $g_{\text {lokal }}=(9,799 \pm 0,001) \mathrm{m} / \mathrm{s}^{2}$. Hasil dari penelitian ini diharapkan dapat memperkaya referensi mengenai penentuan nilai gravitasi bumi di daerah yang dekat dengan ekuator.
\end{abstract}

Kata-kata kunci: Nilai Gravitasi lokal, Hukum Newton, Ayunan Matematis.

\section{DETERMINING SAM RATULANGI UNIVERSITY'S LOCAL GRAVITY ACCELERATION BASED ON HARMONIC OSCILLATION THEORY}

\begin{abstract}
The aim of this study is to determine the value of the local gravitational acceleration at the Sam Ratulangi University in Manado. The method used in this research is a combined method. Theoretical calculations uses the Newton's Law of Gravitation and Newton's Second Law and the experimental method uses a pendulum swing in which there are mathematical numerical analysis and calculation errors/error. Result from data analysis shows the value of local gravitation is $\mathrm{g}_{\text {local }}=(9,799 \pm 0,001) \mathrm{m} / \mathrm{s}^{2}$. The results of this study are expected to enrich reference of determining the value of earth local gravity in an area near to the equator.
\end{abstract}

Keywords: Local Gravitational Value, Newton's Law, Pendulum.

\section{PENDAHULUAN}

Suatu benda yang dilepaskan dari ketinggian tertentu di atas permukaan tanah, pasti akan jatuh ke tanah. Benda tersebut akan jatuh dengan percepatan yang disebabkan oleh adanya gaya gravitasi bumi atau gaya tarik bumi. Gaya tarik bumi ini menyebabkan suatu benda jatuh dari ketinggian tertentu dengan percepatan yang disebut sebagai percepatan gravitasi bumi. Percepatan gravitasi ini dipengaruhi oleh jarak suatu benda dari pusat bumi dan kemasifan susunan bumi di tempat tersebut (Tipler, 1998).

Penentuan percepatan gravitasi bumi secara lokal dapat dilakukan dengan beberapa cara diantaranya dengan menggunakan sistem pegas-massa, gerak parabolik dan sistem pendulum. Kekurangan dari sistem pegas- massa yaitu osilasi yang tidak dapat teramati dengan baik (Usayidah, 2015), sementara kekurangan dari metode gerak parabolik yakni benda akan terlalu cepat sehingga membutuhkan peralatan yang sudah canggih seperti high speed camera dan perangkat lunak pendukung (Afifah, 2015). Penentuan nilai gravitasi bumi lokal yang akan dilakukan dalam penelitian ini yaitu menggunakan sistem pendulum atau yang lebih dikenal dengan nama ayunan matematis Cara ini lebih mudah dilakukan dan tidak membutuhkan peralatan yang sangat canggih. Selain itu penelitian ini sangat penting dilakukan karena dapat membantu pembelajaran fisika dalam pembuktian teori gravitasi secara eksperimen.

Berdasarkan hal di atas maka akan dilakukan penelitian untuk menentukan nilai percepatan gravitasi local di UNSRAT 
dengan menggunakan ayunan matematis. Tahapan dalam penelitian ini yaitu: (1). Menetukan nilai percepatan gravitasi berdasarkan hukum Gravitasi dan hokum II Newton, selanjutnya (2). Melakukan analisa terhadap data eksperimen ayunan matematis.

\section{TINJAUAN PUSTAKA}

Pada abad 16 Masehi Isaac Newton mengemukakan, bahwa ternyata ada suatu gaya pada suatu jarak tertentu yang memungkinkan dua benda atau lebih saling berinteraksi. Newton menyimpulkan bahwa gaya gravitasi atau gaya tarik-menarik dapat berlaku secara universal dan sebanding oleh massa masing-masing benda dan berbanding terbalik dengan kuadrat jarak kedua benda (Giancoli, 2009), dan dirumuskan:

$$
F_{12}=F_{12}=F=\mathrm{G} \frac{m_{1} m_{2}}{r^{2}}
$$

Dengan :

$F_{12}=F_{12}=F=$ gaya tarik-menarik antara kedua benda $(\mathrm{N}), \mathrm{m}_{1}=$ massa benda $1(\mathrm{~kg})$, $\mathrm{m}_{2}=$ massa benda $2(\mathrm{~kg}), r=$ jarak antara kedua pusat benda $(\mathrm{m}), \mathrm{G}=$ tetapan gravitasi universal $\left(6,67 \times 10^{11} \mathrm{Nm}^{2} / \mathrm{kg}^{2}\right)$.

Dengan mengunakan $m_{1}$ sebagai massa bumi $\left(M_{B}=5,98 \times 10^{24} \mathrm{~kg}\right)$ dan $m_{2}$ sebagai objek yang bermassa $m$ yang terpisah dari pusat bumi sejauh $r_{B}$ (jari-jari bumi $=6,38 \mathrm{x}$ $10^{6} \mathrm{~m}$ ), maka persamaan menjadi (Halliday dan Resnick, 2010) :

$F=\mathrm{G} \frac{M_{B} m}{\left(r_{B}\right)^{2}}$

Berdasarkan Hukum II Newton, gaya yang bekerja pada benda bermassa $m$ akan mengalami percepatan $a$ dapat dirumuskan sebagai berikut :

$F=m \cdot a$

Jika persamaan (2) dan persamaan (3) digabungkan, maka akan didapatkan :

Sehingga,

$$
m \cdot a=\mathrm{G} \frac{M_{B} m}{\left(r_{B}\right)^{2}}
$$

$$
a=\mathrm{G} \frac{M_{B}}{\left(r_{B}\right)^{2}}
$$

Dengan menggantikan percepatan $a$ menjadi percepatan gravitasi bumi $g$, maka :

$g=\mathrm{G} \frac{M_{B}}{\left(V_{B}\right)^{2}}$

dengan $; g=$ percepatan gravitasi bumi $\left(\mathrm{m} / \mathrm{s}^{2}\right)$, $G=$ tetapan gravitasi universal $\left(6,67 \times 10^{11}\right.$ $\left.\mathrm{Nm}^{2} / \mathrm{kg}^{2}\right), M_{\mathrm{B}}=$ massa bumi $\left(5,98 \times 10^{24} \mathrm{~kg}\right)$, $r_{\mathrm{B}}=$ jari-jari bumi $\left(6,38 \times 10^{6} \mathrm{~m}\right)$.
Gerak osilasi yang sering kita jumpai adalah gerak ayunan. Gerak osilasi ini berlangsung di bawah pengaruh gaya gravitasi bumi. Jika simpangan ayunan tidak terlalu besar, maka bentuk osilasinya adalah gerak harmonik sederhana.

Jika sebuah titik bermassa $m$ digantungkan (oleh seutas tali tak bermassa) di titik $\mathrm{O}$, dan massa $m$ disimpangkan sehingga membentuk sudut $\theta$ terhadap sumbu vertikal di titik $O$ tersebut. Setelah m dilepas akan bergerak menuju titik setimbangnya oleh gaya balik $\mathrm{F}$ yang merupakan komponen dari gaya berat pada m. Jika panjang tali tersebut adalah $l$, dan percepatan gravitasi bumi $g$ maka $\mathrm{F}$ dapat ditulis sebagai (Tim Fisika Dasar, 2014):

$$
F=-m g \sin \theta
$$

Untuk simpangan yang kecil dapat diambil pendekatan $\sin \theta \approx \theta$.

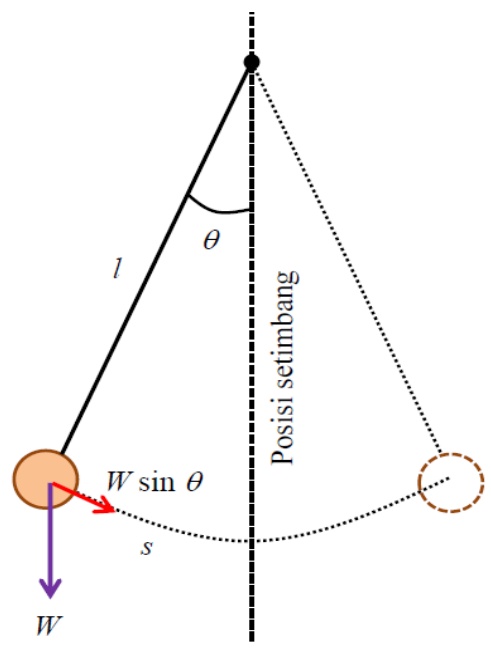

Gambar 1. Ayunan Matematis (Abdullah, 2016)

Besar simpangan benda adalah $\mathrm{s}=l \theta$ dimana $l$ adalah panjang tali bandul dan sudut $\theta$ dinyatakan dalam radian. Dengan demikian, gaya penarik benda ke arah posisi setimbang. menjadi $F=-m g(s / l)=-(m g / l) s$.

Untuk ayunan tersebut bersifat sebagai getaran selaras sederhana maka tidak terdapat (kalau pun ada dapat diabaikan) gaya gesekan udara maupun gaya puntiran pada tali sehingga persamaan gaya resultannya adalah:

$$
\frac{d^{2} F}{d t^{2}}=\frac{g}{l} S
$$


Persamaan (6) merupakan persamaan getaran selaras sederhana dan $\mathrm{S}$ merupakan fungsi periodik dengan perioda $T$ yang memenuhi persamaan:

$$
T=2 \pi \sqrt{\frac{l}{g}}
$$

sehingga didapatkan untuk nilai $\mathrm{g}$,

$$
g=\frac{4 \pi^{2} l}{T^{2}}
$$

Dalam penelitian ini perhitungan nilai gravitasi akan didasarkan pada persamaan (7) selanjutnya akan dilakukan analisis terhadap hasil yang didapatkan.

\section{HASIL DAN PEMBAHASAN}

Data yang digunakan dalam penelitian ini adalah data-data eksperimen yang dilakukan dengan bandul/ayunan matematis. Tabel 1 adalah data pengukuran ayunan pada beberapa panjang tali yang berbeda. Setiap panjang tali diambil tiga kali pengukuran waktu untuk lima belas kali getaran kemudian dirata-ratakan.

Hasil yang didapatkan berdasarkan perhitungan secara teoritis untuk nilai gravitasi bumi yakni dengan menggunakan Hukum Gravitasi Newton adalah $g=9,806$ $\mathrm{m} / \mathrm{s}^{2}$.

Berdasarkan perhitungan manual yang dilakukan dengan menggunakan kalkulator didapatkan nilai $g_{1}=9,796 \mathrm{~m} / \mathrm{s}^{2} \quad$ Sehingga jika dirata-ratakan didapat $\mathrm{g}_{\text {lokal }}=$ $(9,799 \pm 0,001) \mathrm{m} / \mathrm{s}^{2}$.

\section{KESIMPULAN}

Pengukuran nilai gravitasi secara eksperimen dapat dilakukan dengan beberapa cara, salah satunya dengan menggunakan ayunan matematis. Dalam penelitian telah digunakan ayunan matematis untuk mengukur nilai percepatan gravitasi bumi di Universitas Sam Satulangi Manado. Berdasarkan hasil perhitungan secara teoritis didapatkan nilai gravitasi secara umum sebesar $\mathrm{g}=9,806 \mathrm{~m} / \mathrm{s}^{2}$. Dari hasil pengolahan data didapatkan nilai gravitasi lokal di UNSRAT sebesar g gokal $=(9,799 \pm 0,001) \mathrm{m} / \mathrm{s}^{2}$.

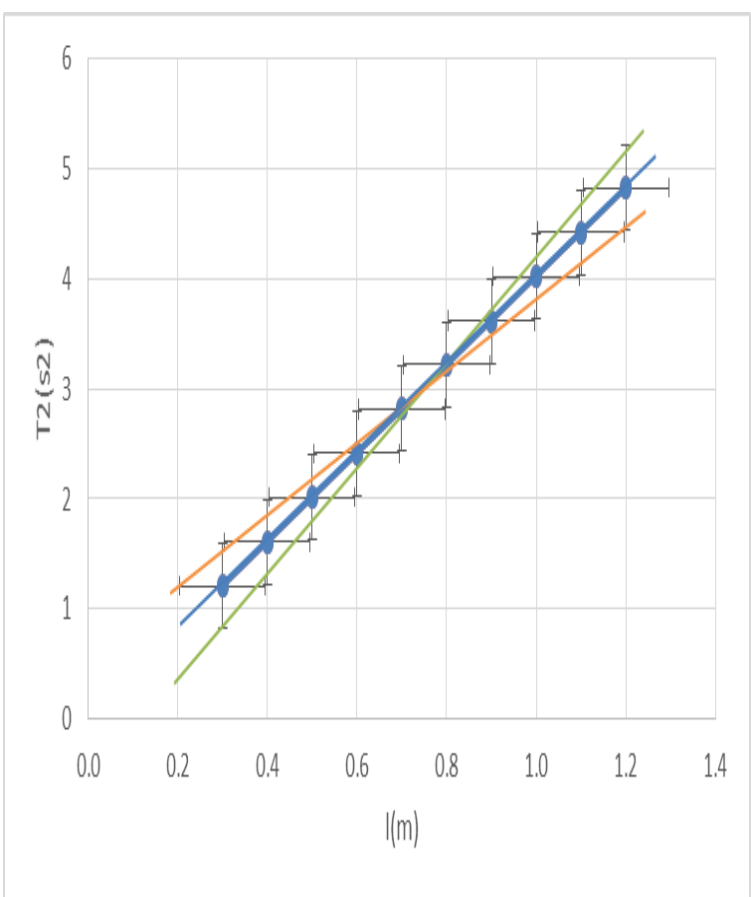

Gambar 2. Plot hubungan antara periode getaran dengan panjang tali bandul.

Tabel 1. pengukuran ayunan pada beberapa panjang tali yang berbeda

\begin{tabular}{|c|c|c|c|}
\hline No. & $l(\mathrm{~m})$ & $\mathrm{t}_{\text {rata-rata }}(\mathrm{s})$ & $\mathrm{T}(\mathrm{s})$ \\
\hline 1. & 1.2 & 33.42333333 & 2.197542 \\
\hline 2. & 1.1 & 31.8 & 2.103986 \\
\hline 3. & 1.0 & 30.64 & 2.006072 \\
\hline 4. & 0.9 & 29.21333333 & 1.903127 \\
\hline 5. & 0.8 & 27.59 & 1.794286 \\
\hline 6. & 0.7 & 26.11666667 & 1.678401 \\
\hline 7. & 0.6 & 24.42333333 & 1.553897 \\
\hline 8. & 0.5 & 22.26 & 1.418507 \\
\hline 9. & 0.4 & 20.15 & 1.268752 \\
\hline 10. & 0.3 & 17.58333333 & 1.098771 \\
\hline
\end{tabular}

\section{DAFTAR PUSTAKA}

Afifah, D. N.dkk. 2015. Metode Sederhana Menentukan Percepatan Gravitasi Bumi Menggunakan Aplikasi Tracker Pada Gerak Parabola Sebagai Media dalam Pembelajaran Fisika SMA. Prosiding SNIPS 2015. ITB Bandung. Hal 305-308.

Giancoli, D. C.2009, FISIKA, Jilid 1, Edisi keempat, Alih bahasa : Imawan, C. Jakarta : Erlangga

Halliday, D. dan Resnick, R. 2010, FISIKA, Jilid 1, Edisi Ketujuh, Alih bahasa : Tim Pengajar ITB. Jakarta : Erlangga. 
Kanginan M, 2007. FISIKA untuk SMA Kelas $X I$, Jilid 2, Jakarta : Erlangga.

Tim Fisika Dasar, 2014 : Panduan Praktikum Fisika Dasar, Laboratorium Fisika Dasar FMIPA UNSRAT. Manado

Tipler, P. A.1998, FISIKA Untuk Sains dan Teknik, jilid 1, Edisi ketiga, Alih bahasa : Prasetyo, L. dan Adi R. W. Jakarta : Erlangga.

Usadiyah dan Rahmawati, E. 2015. Penentuan percepatan gravitasi bumi lokal menggunakan model osilasi gerak pendulum. Jurnal Inovasi Fisika Indonesia Vol.4 No.2. hal 16-20.

Young, H. D. dan Freedman, R. A. 2002; FISIKA Universitas, Jilid 1, Edisi kesepuluh Alih bahasa : Juliastuti, Endang, Jakarta : Erlangga 